\title{
Celtic Correspondences: \\ Letters from Whitley Stokes to Adolphe Pictet and from Henri d’Arbois de Jubainville to \\ ERNST WindisCH
}

Bernhard Maier

\section{Introduction}

On 15 August 1894 Kuno Meyer wrote to Ernst Kuhn, then Professor of Aryan Philology and Comparative Indo-European Studies in Munich: ${ }^{1}$

Dear Professor,

It is very important to me to know whether the library of Johann Kaspar Zeuss was transferred to Munich after his death (1856). Might I ask you to make enquiries some time when you are there again, and also let me know if possible whether any manuscript material of any kind from his pen is to be found in the books or anywhere else? You would oblige me greatly by this. I have recently been to Kronach, Zeuss's home town, and did not find as much as a single line or a book of his. It is all scattered into the wide world.-From mid-September my address will be once more University College, Liverpool.

With my best thanks in advance,

Sincerely yours,

Kuno Meyer ${ }^{2}$

While Kuhn's answer to Kuno Meyer does not seem to have survived the vicissitudes of time, its contents may be inferred from the letter which its recipient sent

1. For an edition of the German original see Maier 2016. The translation of relevant passages in German and French throughout the article was carried out by the author.

2 "Sehr geehrter Herr Professor! Es liegt mir sehr daran zu wissen, ob die Bibliothek von Joh. Kaspar Zeuss nach seinem Tode (1856) nach München gekommen ist. Dürfte ich Sie bitten, gelegentlich, wenn Sie wieder dort sind, nachzufragen; auch mir ev. zu sagen, ob Handschriftliches von ihm irgend welcher Art in den Büchern oder sonst zu finden ist? Sie würden mir dadurch eine große Gefälligkeit erweisen. Ich war neulich in Kronach, der Heimat von Zeuss, u. fand auch nicht eine einzige Zeile od. ein Buch von ihm mehr vor. Alles in die weite Welt zerstreut. - Von Mitte Sept. an ist meine Adresse wieder University College, Liverpool. Mit bestem Dank im voraus Ihr sehr ergebener Kuno Meyer" (Maier 2016: 109). 
in response, telling Kuhn on 18 December 1894 that he would not like to molest him any further with a matter which in the end would yield only insignificant results, for he had been compelled to give up his plan to collect materials for a biography of Zeuss as hardly anything could be gleaned from those few acquaintances of Zeuss that were still alive. ${ }^{3}$ About a month before, Meyer had already told his old teacher Ernst Windisch:

He [Zeuss] seems to have led a rather solitary life, which of course was only natural in Vogtendorf. Incidentally, the two priests who I was told were close friends of his (and who are still alive at a ripe old age in Bavaria) informed me by letter that they had known him only superficially. One of them was called to administer him the last sacrament, but found that he had already passed away. For this reason I cannot, as I had hoped, put together something about the life of Zeuss and publish it, but when we publish our journal I hope to adorn the first volume with his portrait. ${ }^{4}$

In the end, it was not the Zeitschrift für celtische celtische Philologie 1 (1897) but rather Celtica 3 (1856) which was to be adorned with the portrait of Zeuss. ${ }^{5}$ Nevertheless, the above-quoted letters of Kuno Meyer are not without interest, for without them we would never have known about the considerable efforts that he made in order to pay the founder of Celtic Studies his respect, realising that it is only by studying the origins and history of an academic discipline that one can fully appreciate its present state and its place in society. Victor Tourneur's Esquisse d'une histoire des etudes celtiques, the first monograph history of Celtic Studies, was published as early as 1905, but in a private letter to J. Glyn Davies written immediately on its publication Kuno Meyer found it "very disappointing" and "not even a good book of reference". More than a hundred years later, a comprehensive history of Celtic Studies still remains to be written, but anybody waiting for it may draw comfort from the fact that in the age of digitisation the vast amount of unpublished manuscript material is so much more readily available to the researcher that such a volume is bound to be both more comprehensive and more colourful than anything that could have been

3. Maier 2016: 111.

4. "Er scheint recht einsam gelebt zu haben, was in Vogtendorf freilich natürlich war. Die beiden Priester, die mir als besonders befreundet mit ihm genannt wurden, und die beide noch in hohem Alter in Bayern leben, schreiben mir übrigens, dass sie ihn nur ganz oberflächlich gekannt hätten. Der eine von ihnen wurde gerufen, ihm das letzte Sakrament zu erteilen, fand ihn aber schon verschieden. Es ist mir daher auch nicht möglich, wie ich gehofft hatte, irgend etwas über das Leben von Zeuss zusammenzustellen $\mathrm{u}$. zu publizieren, doch hoffe ich, wenn unsere Zeitschrift zu Stande kommt, das erste Heft mit seinem Bildnisse zu schnücken” (Maier 2016: 110).

5. See Hablitzel 1987: appendix no. 31, and cf. the contributions in Hablitzel and Stifter 2007.

6. See Maier 2017: 109. 
achieved a generation ago. The following extracts from letters written by outstanding scholars during the formative early years of the newly established discipline will hopefully serve to illustrate the point.

\section{The letters of Whitley Stokes to Adolphe Pictet}

When Johann Caspar Zeuss laid the foundations of modern Celtic Philology with his Grammatica Celtica (1853), he had at least three immediate forerunners: the English physician and anthropologist James Cowles Prichard (1786-1848) with his book The Eastern Origin of the Celtic Nations (1831), the Swiss specialist in ballistics and amateur linguist Adolphe Pictet (1799-1875) with his essay 'De l'affinité des langues celtiques avec le sanscrit' (1836), and the German founding father of Comparative Philology Franz Bopp (1791-1867) with his treatise 'Über die celtischen Sprachen vom Gesichtspunkt der vergleichenden Sprachforschung' (1838). However, as Prichard had died as early as 1848 and Bopp had moved on to studying other branches of Indo-European, it was only Adolphe Pictet who continued his Celtic researches in the wake of Zeuss' seminal work, publishing articles in scholarly periodicals and corresponding with fellow scholars in Ireland, Britain, France and Germany. For the last sixteen years of his life, Pictet exchanged letters with Whitley Stokes, who was just beginning to make his name in Celtic Philology at that time. While Pictet's letters to Stokes have yet to be traced, 26 letters and two postcards from Stokes to Pictet are extant among the papers of Adolphe Pictet in the Library of Geneva.? The correspondence appears to have begun in the spring of 1859, after the Swiss scholar had sent Stokes a copy of his lengthy Essai sur quelques inscriptions en langue gauloise (in which he had consistently misspelt Stokes' first name, writing 'Whitney' instead of 'Whitley'). Despite this blunder Stokes was evidently gratified at this recognition of his work and replied within less than a week, gratefully acknowledging the gift while eagerly taking the opportunity to submit alternative interpretations on philological points of detail: ${ }^{2}$

7. Bibliothèque de Genève, Ms. fr. 4229, ff. 153-211, 214-221, 147v.

8. Ms. fr. 4229, ff. 153-154. In my quotations from Stokes's letters, I have replaced Greek and Irish characters by their Latin equivalents, italicising the words in question. Italics are also used for words which Stokes underlined. 
3 New Square

Lincolns Inn. London.

March 3. 1859.

Sir

I beg leave to return my thanks for your kindness in sending me a copy of your essay (which reached me only on Monday last), as well as for the flattering manner in which you have mentioned my name therein. I had previously studied the inscriptions given by M. de Belloguet, \& had, I am proud to say, arrived at one or two of your conclusions (e. g. I had recognised dugiiontiio as the nom. sg. of a stem in tiôn). There are, however, a few points in which I cannot bring myself to agree with you; $\&$ these will, I trust, be noticed by you in a $2^{\text {d }}$ edition of your essay.

In what follows, Stokes meticulously listed additions and corrections on some fifteen points of detail, noting among other things that Gaulish "namaus-ati-s is surely to be compared with Latin stems like Arpin-ati, Aquin-ati", that Gaulish "eiōrou cannot be connected with iarraim (there is no such word as iaraim-O'Reilly has misled you)", that Gaulish sosin "cannot be compared with the Irish sosin, for the second $s$ in the Gaulish form would certainly have been lost between the vowels", that Gaulish etic seems to him "a conjunction eti-c 'and', the c being the pronominal enclitic so common in Latin \& Umbrian", and that Gaulish VCVETIN was "surely an acc. sg. of an i-stem like RATI-N”. He concluded his letter by writing:

I cannot help expressing my belief that there are more Gaulish inscriptions lying unnoticed in the provincial museums of France. I have no doubt that there are some in Galatia. With the earnest hope that your investigations may tend to direct attention to these valuable linguistic relics, I have the honour to remain

your obedient servant

Whitley Stokes.

As a postscript he added:

You will be glad to know that Siegfried is now Professor of Sanskrit \& Comparative Philology in the University of Dublin; also that Edwin Norris (decipherer of Cuneiform inscriptions) has just completed an edition of the Cornish drama. Have you Duchalais? I have not yet had time to see whether CASSIA TOVTA SEGVSIAV(A) Glück K N. 153 is all Gaulish.

Occupying four closely written pages, Stokes' first letter to Pictet may be said to be fairly typical of those that were to follow - both in its length and in its style and 
contents. On the one hand, Stokes was always ready to pay deference to the older and more experienced scholar (who was, after all, five years older than his own father), but on the other hand, he was also keen to assert views of his own, commenting on the ideas of his correspondent, and correcting interpretations which he thought erroneous. Moreover, he passed on information concerning new discoveries, work in progress, and the doings of other Celticists. Reading Stokes' letters to Pictet today, the most interesting passages are those in which he refers to newly discovered material that has long since become classic and those in which he talks about his fellow scholars, bringing to life a range of names which most modern students of Celtic only know from the battered leather spines and foxy title-pages of those stately, well-worn volumes dating back to the early days of the discipline.

A prominent feature in this correspondence is the two scholars' mutual interest in Continental Celtic. ${ }^{9}$ As the sum total of Gaulish inscriptions known today is not so much larger than it was 150 years ago, Stokes' comments on them tend to round up the usual suspects, a provisional list of familiar names including the wellknown inscriptions from Alise-Sainte-Reine, Vaison, Vieux-Poitiers and Todi. Some of Stokes' interpretations are rather wide of the mark, such as the above-quoted analysis of the form dugiiontio, which is now generally taken to be the third person plural of a present relative form, corresponding to Old Irish bertae. On the other hand, Stokes in several instances already gave what is still regarded as the correct interpretation - or at least as one of several plausible possibilities. With regard to the Todi inscription, Stokes' interpretation was pioneering, as he himself realised:10

Lottner (as he himself $\mathrm{w} d$ be the first to acknowledge) had nothing to do with determining the Celticity of the Todi-inscription. I am rather proud of this inscription, as I persisted in my view notwithstanding a severe snub (as we say) from Aufrecht, to whom in my innocence I communicated my discovery.

Unsurprisingly, in those days there were still doubts on the Celticity of several other Gaulish texts, Stokes telling Pictet in a letter dated Easter Sunday 1859:11

You \& Jacob Grimm will probably now see fit to change your readings of the formulas of Marcellus - now, I mean, since the publication of the Gaulish inscriptions. One, for instance, (which I quote from memory) you will probably read

9. See Blom 2011.

10. Letter dated 6 December 1867 (Ms. fr. 4229, ff. 193-194).

11. Ms. fr. 4229 , ff. $157-158$. 


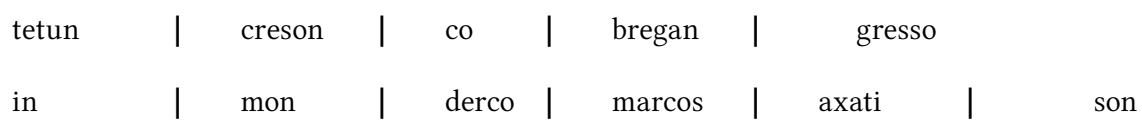

I follow Siegfried in translating in mon derco "in meo oculo". Marcos nom. sg. gresso gen. sg. bregan acc. sg. of a fem. â-stem. Pity it is that the reading of these formulae are so doubtful. I suspect axati to be a verb in the $3^{\text {rd }} \mathrm{sg}$. pres. indic. act. You mention in your Essai that Zeuss acknowledged their celticity. Have you a copy of his letter? It would be very precious to Siegfried \& myself.

Apart from their common interest in Old Celtic inscriptions, Stokes also shared Pictet's interest in the Gaulish personal names that had been preserved by classical authors, writing from Calcutta on 1 Jan. 1868:12

I have lately read the latter half of your paper on Gaulish names compounded with epo-, marco-etc. (the first half is not procurable here!). Could not epo-in some of these names have sunk down to merely an intensive prefix, like march-in Welsh \& horse-in English? Epo-so-gnâtos hochwohlgeboren!

He was also delighted when he learnt that Pictet planned to make a study of Gaulish river names, telling him on 12 January 1869, "If I can contribute anything which you think of value I shall be not only happy but proud". ${ }^{3}$

As an example of Stokes' interest not only in Gaulish names, but in all sorts of Celtic words transmitted by classical authors, one might quote in full the following card written at Simla on 17 August 1874:

My dear Monsieur Pictet

A conjectural emendation of Pliny, which has just occurred to me, will, I think, interest you. Plin. XVIII c. 40, cited by Diefenbach Origg. Eur. 235 "Secale Taurini sub Alpibus asiam vocant." For asiam read sasiam (the initial s was dropt owing to the final s of the preceding word), and we get the Old Celtic equivalent of Skr. sasya "granum", Zend hahya, which Rhys had already found in Welsh haidd 'barley'.

I hope you will approve of this \&, if so, that it may be in time for the new edition of Origines. It is a pity that sasya is neuter, sasia feminine \& haidd masculine: mais dans ce monde on ne peut pas avoir toute chose.

Yours very sincerely

Whitley Stokes

12. Ms. fr. 4229, f. 199.

13. Ms. fr. 4229 , ff. $202-203$. 
Turning from Continental Celtic to the Insular Celtic languages, we may note that Stokes was mainly concerned with the mediaeval forms of Insular Celtic, and that although Welsh and Breton were not neglected, Old and Middle Irish clearly took pride of place in his researches. While his work on Continental Celtic was often about the correct grammatical analysis of a given form, one of his main interests in Irish Philology was to establish the correct meaning of lexical items and to eliminate ghost-words which continued to be taken at face value by Indo-Europeanists unfamiliar with the problems of Irish lexicography. Having been told that Gaulish eiorou could not possibly be connected with Irish iarraim, his Swiss correspondent appears to have pointed to O'Donovan as his authority, upon which Stokes declared: ${ }^{14}$

Anything that O’Donovan or (still more) Curry, say about Irish words deserves attention. But I think they are both wrong about iarraim. I have never met this form in a ms. always iarfaigim. And you observe neither of them gave Siegfried an instance of the occurrence of iarraim.

In a similar vein, Stokes told Pictet some months later: ${ }^{15}$

I strongly suspect the Celticism of maistir. Curry has never seen it in a ms. \& believes it to be quite a modern word. It is used, he says, as a delicate expression for urine in the South. Perhaps it may be nothing but the English moisture.

As is plain from many scathing references, Stokes' bête noire in the field of Celtic lexicography was Edward O’Reilly (1765-1830), whom Pictet had innocently taken as a respectable authority. However, when Stokes received the second volume of Pictet's Origines indo-européennes, he was delighted to find that his warnings had been heeded: ${ }^{16}$

First let me congratulate you on the healthy scepticism regarding O'Reilly which you shew in several places, and which I trust you will continue to cultivate. [...] O’Reilly was grossly ignorant \& did not possess even a vernacular knowledge of Irish.

When Pictet told him that that he was going to prepare a second edition of his book, Stokes recommended that he also consult John Rhŷs, as it was "most desirable that a classical work like yours $\operatorname{sh}^{d}$ be freed from the forgeries $\&$ blunders of Pughe \& O’Reilly."17

\footnotetext{
14. Letter dated Easter Sunday 1859 (Ms. 4229, ff. 157-158)

15. Letter dated 30 July 1859 (Ms. fr. 4229, ff. 167-168).

16. Letter dated 16 September 1863 (Ms. fr. 4229, ff. 179-190).

17. Letter dated 27 February 1874 (Ms. fr. 4229, ff. 210-211).
} 
As appears from a letter which he wrote on 6 February 1860, Stokes did not expect any short-term solution to the difficulties besetting Irish lexicography, telling Pictet in a kind of grim resignation: ${ }^{18}$

You will I fear never have a thesaurus of the Irish language unless some German scholar comes and does it. Curry \& O’Donovan are getting old \& do not work cordially together; and there is no one else competent. Even they could not produce such a work as modern scholar-ship demands \& has a right to expect. They are still confused by the blundering rules of the native Irish grammarians \& translate hápax legómena (of which there are a large number) with the most surprising rashness. Meanwhile the best thing to do is to print all attainable glosses \& glossaries, of which there are many.

Occasionally we also get glimpses of exciting new discoveries that continued to be made in libraries, Stokes informing Pictet in the very same letter:

You will be glad to hear that a ms. formerly belonging to the Abbey of Deer in Aberdeen-shire has been discovered in the Public Library at Cambridge, containing specimens of Scotch Gaelic of the $8^{\text {th }}$ or $9^{\text {th }} \&$ the $13^{\text {th }}$ centuries. They are not extensive, but very interesting.

Turning from matters of philology to personal relationships, the scholar with whom Stokes cooperated most closely and most cordially may safely be taken to have been Rudolf Thomas Siegfried (1830-1863). ${ }^{19}$ From the many instances in which his name is mentioned in the letters to Pictet, it appears that Stokes trusted his scholarly judgment implicitly and without hesitation. Thus Stokes referred to Siegfried's share in the gestation of his own book Irish Glosses in the above-quoted letter by writing:

Indeed whenever you meet with anything you think particularly ingenious you may attribute it to Siegfried - who read all the proofs \& made most valuable suggestions which however he would rarely permit me to acknowledge.

This lavish praise evidently intrigued Pictet, who consequently appears to have asked Stokes about Siegfried's background. Presumably in response to some such question Stokes told him in a letter dated 14 April 1860: ${ }^{20}$
18. Ms. fr. 4229, ff. 169-170.
19. See Ó Dochartaigh 2011.
20. Ms. fr. 4229, ff. 171-172. 
As to my dear friend Siegfried, he is a German (a native of Dessau), but with Slavonic (Bohemian) blood in his veins by the mother's side. I hope to God he will live to finish his book, but fear that he has some complaint in his spine.

The book here mentioned was an introduction to Comparative Philology, about the progress of which Stokes reported to Pictet on 24 March 1861: ${ }^{21}$

You will be glad to hear that he is not now complaining of his health, \& is working steadily at his introduction to Comparative Philology. Whether he will ever finish it, is another question. "While the wise men ponder the fools take the footsteps" is a Servian [i.e. Serbian] proverb which, I fear, is very applicable to his case.

The following short note in a letter to Pictet dated 4 August 1861 refers to what may well have been the last occasion on which Siegfried and Stokes saw each other before the latter departed to India: ${ }^{22}$

Our friend Siegfried surprised me by walking in here last Friday on his way to Dessau for his vacation. He looked very well \& as happy as a man ought to be under such circumstances. I despair of his ever finishing his Introduction to Comp. Philology. He has a morbid love for unattainable perfection.

Writing from Madras on 16 September 1863, Stokes referred to Siegfried's death in terms which leave no doubt about how keenly he felt this loss: ${ }^{23}$

But you have doubtless heard as I have since I came to India of the deplorable death of Siegfried - a death brought on by relentless unremitting study. The last by-work which he did was an essay on your Gontauros inscription, which Lottner has published in the Proceedings of the Royal Irish Academy. His death has taken from my life half its brightness and hope.

All the more pleased Stokes was when he read Pictet's obituary of Siegfried, praising his deceased friend in terms which say much about the way in which he wished to be regarded and regarded himself: ${ }^{24}$

21. Ms. fr. 4229 , ff. $175-176$.

22. Ms. fr. 4229 , ff. $177-178$.

23. Ms. fr. 4229, ff. 179-190.

24. Letter dated 6 October 1867 (Ms. fr. 4229, ff. 191-192). 
What you have said about him will be more than justified by an article called Miscellanea Celtica, which, with much labour, I have put together from over 3000 scraps of paper in his handwriting which Dr Todd sent me some time ago. The article will appear in the Philological Society's Transactions, \& also, I hope, in the Beitraege. I am sorry that you do not speak of Lottner, whose discoveries about the Celtic verb are, in my opinion, quite as important as Ebel's about declension; \& I regret that you $\mathrm{sh}^{d}$ have placed me so nearly on a level with Siegfried, a position which I do not, \& never shall, deserve.

Among the comparative philologists whom Stokes evidently valued less highly was Max Müller, as may be gauged from the following reference in a letter to Pictet dated 4 August 1861:25

M. Müller's "Lectures on the science of language", which have just been published, will, I trust, make the English cease to regard our science as the guesswork of foolish learned men.-But his orthodoxy, which is more than English orthodoxy-makes him say strange things about his three families of languages \& I know not what. And the book will not increase his reputation in Germany.

Nevertheless, Stokes was always measured in his criticism of other scholars - at least in his letters to Pictet and, one might add, in those to Adalbert Kuhn. Thus he told Pictet on 24 March 1861:26

Your friend Weber has just received a formidable castigation in Goldstücker's book on Pânini which accompanies a facsimile of the Mânava-kalpa-sûtra. Kuhn, too, \& Böhtlingk are not spared. Altogether it is a savage onslaught, reminding one of the way scholars of the $17^{\text {th }}$ century used to call one another porcus quidam.

As regards the situation of Celtic Studies in general, he gave a rather gloomy assessment in a letter dated 12 October 1874:

I am very glad you have got the second ed $^{n}$ of Goidelica. I fear that poor Trübner the publisher will lose heavily by the book, there is so little demand for such publications in England, and not at all in Ireland.-Anything more deplorable than the state of Celtic studies in Ireland you can hardly conceive. Zeuss \& Ebel have (so far as the Irish are concerned) laboured in vain. Then the religious difficulty comes into play.

25. Ms. fr. 4229, ff. 177-178. For recent appreciations of Max Müller and his role in Victorian philology and linguistics, see Davis and Nicholls 2018.

26. Ms. fr. 4229 , ff. $175-176$. 
The priests are in an agony lest anything sh $d$ be published likely to discredit their Church, \& this leads to suppressions \& falsifications. The printing of my three-text edition of the Calendar of Oengus (which the Royal Irish Academy undertook) has been stopped after it had got down to May 21-why? I believe because I refused compliances with the request of Cardinal Cullen's secretary to suppress those stories of Créd's pregnancy \& Becnait's impregnation - they occur as marginal notes to the Lebar Brecc copy of the Calendar of Oengus-published in the Revue celtique IV, 199, 200. In Irish matters the Academy is wholly under the dominion of Catholic priests \& bishops.

Small wonder that the small band of Celticists should occasionally have felt that they had to brace themselves and face a sea of troubles, Stokes telling Pictet in a letter from Calcutta on 12 January 1869: ${ }^{27}$

I, too, have often thought of the fate that seems to persecute Celtic scholars: Zeuss, Glück, Siegfried, O’Donovan, Curry dead, Todd dying, myself in exile. But courage! You \& Ebel are still at work, Ascoli proposes to print the great Milan codex, and M. Gaidoz tells me that a distinguished German scholar-Giesler - (who is he?) has just been appointed to a chair in Galway \& is going to study Irish. When one soldier falls another of the little band is ready to take his place in the ranks. In 1871 I hope to return to Europe for a year and then to have the happiness of making your personal acquaintance.

As regards the final remark in this passage, it may be noted that Stokes only rarely referred to his own condition or to his own future plans, except in connection with scholarly projects. Thus he reported to Pictet on 16 September $1863:^{28}$

In the autumn of 1861 I was near you - having gone to Turin \& got the O. Ir. glosses there; thence to Milan where is a ms. black with Ir. glosses; thence, over the Weisz Thor, to Zermatt, \& so to Berne, when I got the Ir. glosses on the Horace which Orelli makes known in the preface to his edition. These please God shall all be printed soon.

Some more remarks about his situation in India are to be found in the same letter:

Since my arrival I have been appointed Reporter to the High Court and also Acting Administrator General. The last is a lucrative appointment \& I have been enabled to indulge myself in printing the Félire Oengusso - the longest \& most important of

27. Ms. fr. 4229 , ff. $202-203$.

28. Ms. fr. 4229 , ff. $179-190$. 
our Old Irish poems. The text is already printed. I am going on with the translation \& intend to add a glossary, which will be a good step to making an Irish Dictionary. During my voyage from England I amused myself transcribing \& translating a Cornish play on the Creation \& the Flood, of which the ms. is in Oxford.

As is evident from this passage, Stokes' professional career in India was something of a mixed blessing, bringing financial success, but straining both his health and his time. ${ }^{29}$ Thus Stokes told Pictet on 25 September 1868 in a letter from Simla: ${ }^{30}$

I am so deplorably taken up by my heavy official duties that I have scarcely even an hour for philology, and the Govt. is going to give me, in addition to my present office, that of Standing Counsel to the Indian Army.'

Significantly, Stokes is largely silent as regards family matters, mentioning his wife only once in passing and his children not at all. All the more revealing is the following passage in a letter dated 4 August 1861:

I am ashamed of having left your last letter so long unanswered, but there has been a great sorrow in my family - my favourite sister has died - and I have been disinclined to write more than was absolutely necessary.

As the only occasion on which Stokes talked politics in his letters to Pictet, one might finally quote his comment about political tensions between Switzerland and France: ${ }^{31}$

You rejoice me greatly by what you say as to the spirit of your countrymen. Ah if I were prime-minister of England you should not have to rest satisfied with mere expressions of sympathy. I would say to Louis Napoleon: Stop arming, stop building warships, stop throwing Europe into chronic alarm and irritation, or fight-and God defend the right. We $\mathrm{sh}^{d}$ never have heard of the annexation of Savoy if our cabinet had had the manliness to say so six months ago-But it is a cabinet d'aisance.

"I feel very much gratified \& honoured by the gift of your portrait", Stokes told Pictet in the autumn of 1875 , some three months after he had sent him his own photograph at the latter's explicit request. "You seem so hale and strong that I have good hopes of seeing you when I return to Europe - hopes in which my wife heartily joins." This, however, was to be Stokes' last letter to the Swiss scholar. Dated

29. On Stokes's life in India, see Chancellor 2011.

30. Ms. fr. 4229, ff. 200-201.

31. Letter dated 14 April 1860 (Ms. fr. 4229, ff. 171-172). 
Simla, 23 September 1875, it probably reached his correspondent only weeks before the latter's death on 20 December 1875. Looking at all 126 pages of Stokes' letters to Pictet, the wealth of ideas enshrined in them and the many references to work just printed, in press or in progress, one feels bound to acknowledge that Whitley Stokes amply fulfilled the resolution expressed at the outset of this correspondence, namely that "if time $\&$ health are only spared I trust to do something yet to set these poor old Celtic languages on their legs". ${ }^{32}$

\section{The letters of Henri d'Arbois de Jubainville to Ernst Windisch}

If the beginnings of Celtic Studies in Ireland were intimately bound up with the study of Irish antiquities in the wake of Romanticism, the French interest in all things Gaulish had originated as early as the Renaissance, Guillaume Postel (15181581) publishing his Histoire memorable des expeditions ... faicts par les Gaules in 1552. Some 150 years later, Paul-Yves Pezron (1639-1706) and his Antiquité de la nation, et de la langue des Celtes autrement appelez Gaulois (1703) ushered in the period when Gaulish and Celtic came to be regarded as near synonyms, leading to an enthusiastic reception of the Poems of Ossian in France and the establishment of an Académie celtique in 1804. If the first-ever Chair of Celtic was established at Oxford in 1877, France could boast to have produced the first scholarly journal for the newly established academic discipline, the folklorist Henri Gaidoz (1842-1932) having founded Revue celtique in 1870. Yet when it was decided to establish a Chair of Celtic Language and Literature at the Collège de France in Paris, its first incumbent was not Gaidoz, but an historian and medievalist.

Born in Nancy in 1827, the son of a lawyer, Henri d'Arbois de Jubainville had been a student at the École nationale des chartes from 1845 to 1850 , having subsequently been Director of the Archives départementales de l'Aube from 1852 to 1880. While his main work was an eight-volume Histoire des ducs et comtes de Champagne depuis le VIe siècle jusqu'à la fin du XIe (1859-1869), he had also published a Répertoire archéologique du Département de l'Aube (1861) and a volume on Les premiers habitants de l'Europe (1877). As a Professor of Celtic, his chief legacy came to be his twelve-volume Cours de littérature celtique (1883-1902). As d'Arbois was something of a newcomer to Celtic Studies when he was first appointed to the Paris chair, he sought to establish cordial links with the small band of other scholars tilling the same field. One of these was the German Indo-Europeanist Ernst Windisch, who had picked up Irish from Standish Hayes O'Grady during a stay in London in 1871, being subsequently appointed Professor of Comparative Philology in the universities of Heidelberg, Strasbourg and Leipzig. 43 letters and 13 postcards among the papers of Ernst Windisch in Leipzig University Archive (Nachlass Windisch

32. Letter dated 30 July 1859 (Ms. fr. 4229 ff. 167-168). 
2.7.1-56), the majority dating from the years between 1884 and 1900 , testify to the cordial relationship between the two scholars at a time when Franco-German relations were frequently rather strained. The complimentary tone which d'Arbois generally adopted towards Windisch is evident from the very first of these letters, dated 30 April 1884, in which he praised a recent article by Windisch, reminiscing about a scholarly discussion which he had just had with the latter. ${ }^{33}$

Cher ami, J'ai reçu votre article, je l'ai immédiatement parcouru, mais je ne l'ai pas lu à fond. Je l'ai envoyé à mon relieur. Quand il me reviendra, dans peu de jours, il sera plus commode à étudier à fond. J'ai vu que sous forme d'article vous avez donné la matière d'un volume, très bien disposé et plein de science. Les seuls points sur lesquels je ne suis pas de votre avis sont ceux sur lesquels nous avons déja dit quelques mots, lors de votre aimable visite.

The extent to which d'Arbois was ready to acknowledge Windisch's superior knowledge as an Indo-Europeanist and Celticist is unequivocally stated in a letter dated 21 August 1887: "Je ne parlerai pas des éloges que vous méritez. Quoique plus âgé que vous, je suis votre élève". ${ }^{34}$ Nevertheless, his letters and postcards are generally written in an easy-going conversational tone, which is well exemplified by the following postcard dated 6 August 1890: ${ }^{35}$

Cher ami, Me voici à la campagne, pensant au plaisir que j'ai eu de vous y voir et à celui que j'aurais à vous y revoir. A quoi employez vous vos vacances? Je pense y terminer le second volume des Premiers habitants de l'Europe. Je vais me trouver sur quelques points en désaccord avec vous, comme vous avez pu le voir dans la chronique de la Revue celtique à propos de Rhys. Je vais me servir beaucoup des travaux de Kluge. Qui donc a fait la partie celtique de son Etymologisches Woerterbuch?

33. "My Dear Friend, I have received your article, I have skimmed through it immediately, but I have not read it carefully. I have sent it to my binder, and when it is returned to me in a few days, it will be more convenient to study it in depth. I have seen that under the guise of an article you have given the substance of a book, very well organized and full of scholarship. The only points on which I do not agree with you are those on which we have already had some discussion during your amiable visit” (Nachlass Windisch 2.7.1).

34. "I shall not eulogize you in the way you deserve. Although I am older than you, I am your student” (Nachlass Windisch 2.7.15).

35. "My Dear Friend, Here I am in the country, thinking of the pleasure I have had in seeing you there and of that which I should have in seeing you there again. How do you use your holidays? I propose to finish the second volume of the Premiers habitants de l'Europe. On some points I shall find myself in disagreement with you, as you may have seen from the chronicle of the Revue celtique with regard to Rhys. I shall make copious use of the works of Kluge. Who was responsible for the Celtic part of his Etymologisches Wörterbuch? Give my kind regards to Mrs. Windisch and believe me yours truly H. d'Arbois de Jubainville" (Nachlass Windisch 2.7.29). 
Veuillez présenter mes respectueux hommages à Madame Windisch et me croire votre bien dévoué $\mathrm{H}$. d'Arbois de Jubainville.

Unsurprisingly, the letters contain both references to debates in Celtic Studies (such as a brief discussion of the Celtic origins of Old French veltre in a letter dated 8 October 1886) and the inevitable gossip, d'Arbois telling Windisch in a letter dated 30 April 1884: $:^{36}$

Je reçois à l'instant les Keltische Studien de Zimmer. Il est vraiment très drôle. Il me semble y avoir au fond de cette brochure une découverte intéressante, mais l'auteur y associe des sottises qui ne peuvent porter d'un esprit judicieux.

An interesting aspect of university life is highlighted by a brief reference to an exchange of students, d'Arbois thanking his German friend and colleague for the way in which the latter had welcomed a student of his at Leipzig in a letter dated 19 November $1886:^{37}$

Mon cher ami, Je tiens à vous remercier de la façon si bienveillante dans vous avez accueilli Louis Duvau qui me fait bien de plaisir en me donnant des nouvelles de vos leçons. Il y prend un grand intérêt, notamment à ce que vous dites des neo-grammairiens ; il trouve très amusante la forme que vous savez donner à votre scepticisme.

The fear of an impending war between France and Germany is mentioned in a letter dated 28 October 1887, but on this controversial topic d'Arbois chose to adopt a rather philosophical approach: ${ }^{38}$

36. "I have just received Zimmer's Keltische Studien. He is really a very droll fellow. It seems to me that his booklet is based on an interesting discovery, but the author mixes this up with follies which do not commend themselves to a judicious mind" (Nachlass Windisch 2.7.1).

37. "My Dear Friend, I should like to thank you for the benevolent way in which you have received Louis Duvau, who gives me great pleasure by providing me with news of your lectures. He takes great interest notably in what you say about the neo-grammarians; he finds the form in which you couch your scepticism most amusing" (Nachlass Windisch 2.7.11).

38. "The prospect of seeing Ariovist in my home and of having to choose between the quality of a Lorrain and that of a Frenchman is to me unspeakably painful; I had rather die before it comes to that, although that does not keep me from entertaining a profound affection for you. [...] But I still hope that war will be avoided. For a long time I have seen the same animosity between France and Britain, which exists now between France and Germany, and there was no war" (Nachlass Windisch 2.7.17). 
La perspective de voir Arioviste chez moi et d'avoir à choisir entre la qualité de Lorrain et celle de Français, m'est on ne peut plus pénible; je voudrais mourir avant; ce qui ne m'empêche pas d'avoir pour vous une profonde affection. [...] Mais j'espère toujours que la guerre sera évitée. J'ai vu longtemps entre la France et l'Angleterre la même animosité qu'aujourd'hui entre la France et l'Allemagne et il n'y a pas eu de guerre.

Sadly, however, cordial feelings between individuals did not prevent the international political situation from deteriorating further and further, leading ultimately to the outbreak of that Great War which had been in the minds of politicians, military officers and the public at large for so long. Henri d'Arbois was spared to witness the ensuing ravages, having died at the age of 82 on 26 February 1910. His friend Ernst Windisch died on 30 October 1918, twelve days before the armistice came into force, leaving the letters that he had received from numerous friends and colleagues as a testimonial to that spirit of cordial international cooperation between scholars of widely different backgrounds which may still be upheld as a model.

Eberhard-Karls University of Tübingen

\section{References}

Blom, A., 2011, 'Whitley Stokes and the Study of Continental Celtic', in: Boyle, E., \& Russell, P., eds, The Tripartite Life of Whitley Stokes (1830-1909), Dublin, 134-143. Chancellor, N., 'Patriot Hare or Colonial Hound ? Whitley Stokes and Irish Identity in British India, 1862-81', in: Boyle, E., \& Russell, P., eds, The Tripartite Life of Whitley Stokes (1830-1909), Dublin, 59-77.

Davis, J. R., \& Nicholls, A., 2018, eds, Friedrich Max Müller and the Role of Philology in Victorian Thought, London: Routledge.

Hablitzel, H., 1987, Prof. Dr. Johann Kaspar Zeuss, Begründer der Keltologie und Historiker aus VogtendorflOberfranken, Kronach: Stürzel \& Fehn.

Hablitzel, H., \& Stifter, D., 2007, eds., Johann Kaspar Zeuss im kultur-und sprachwissenschaftlichen Kontext (19. bis 21. Jahrhundert), Wien: Praesens.

Maier, B., 2016, Keltologe zwischen Kaiserreich und British Empire: Kuno Meyers Briefe an Korrespondenten in Deutschland und Österreich, 1874-1919, Würzburg: Ergon.

Maier, B., 2017, Kuno Meyer and Wales: Letters to John Glyn Davies, 1892-1919, Würzburg: Ergon.

Ó Dochartaigh, P., 2011, 'A Shadowy but Important Figure : Rudolf Thomas Siegfried', in: Boyle, E., \& Russell, P., eds., The Tripartite Life of Whitley Stokes (18301909), Dublin, 29-43. 
